\title{
A scientific note on allozyme variability in Persian honey bees (Apis mellifera meda) from the Elburz mountains in Iran
}

\author{
Irfan KANDEMIR $^{\mathrm{a} *}$, Ayca OZKAN ${ }^{\mathrm{a}}$, Mohammed G. MORADI ${ }^{\mathrm{b}}$ \\ a Department of Biology, Karaelmas University, Zonguldak 67100, Turkey \\ $\mathrm{b}$ Department of Biology, University of Zanjan, Zanjan, Iran
}

(Received 15 May 2003; revised 17 December 2003; accepted 29 January 2004)

\section{Apis mellifera meda / isozyme / genetic variation / Iran}

The Persian bee, Apis mellifera meda, was first described by Skorikov in 1929 based on tongue length and shape of the abdominal sternites (Ruttner et al., 1985). In the early description, the distribution is given as North Persia, Lencoron. However, the distribution of $A$. m. meda was extended later to the north of Iraq, Syria and the southeastern parts of Turkey (Ruttner, 1988). Although it is distributed in an area that is important in terms of honey bee evolution (Ruttner, 1988), the honey bees of Iran have been less extensively studied. Morphometric analysis has been used to study variation within $A$. $m$. meda (Ruttner et al., 2000). However there is no study of allozyme variability in honey bees from Iran. Enzyme polymorphisms in honey bee subspecies have been extensively studied (for detail review see Sheppard and Smith, 2000). The objectives of this study were to determine the biochemical variability of Iranian honey bees and to compare the results with published data from surrounding populations.

Honey bee samples were collected in July 2002 from south of the Caspian Sea. The area is mountainous and the highlands reach 2500 meters. Lowland bees are on the plains, in areas not more than 800 meters altitude. Six locations, Hancayi, Sefar,
Zanjan (highlands), Gultepe, Duzteran, Gholikandy (lowlands) were visited and 46 colonies were sampled. Starch-gel electrophoresis was performed (Kandemir and Kence (1995). Allozymes were detected after gels were stained for Est-3 (E.C.3.1.1), Hk (E.C.2.7.1.1), Pgm (E.C.5.4.2.2), $\mathrm{Mdh}$ (E.C.1.1.1.37), $\mathrm{Me}$ (E.C. 1.1.1.40) and $\mathrm{Pgi}$ (E.C.5.3.1.9). Population structure parameters were determined by the BIOSYS-1 package (Swofford and Selander, 1981).

Out of six enzymes assayed, four were found to be polymorphic [Pgm (100 and 128), Hk (87 and 100), Mdh (65, 87 and 100), and Est (70 and 100)] and two [Pgi (100) and $\mathrm{Me}(100)]$ displayed invariant banding patterns. All lowland populations were in $\mathrm{H}-\mathrm{W}$ equilibrium for all enzyme loci, whereas there were deviations from $\mathrm{H}-\mathrm{W}$ equilibrium for $H k$ (all highland) and Mdh (Zanjan) in favor of heterozygotes $\left(\chi^{2}\right.$ test, $\left.P<0.05\right)$. These deviations could have resulted from migratory beekeeping in mountainous areas, whereas, we did not observe any migratory beekeeping operations in lowland areas.

Highland populations were more heterogeneous than lowland populations (Tab. I). The highest and the lowest mean heterozygosity was observed in

Table I. Summary of genetic variation based on six allozyme loci in six populations of A. m. meda in Iran.

\begin{tabular}{lccccc}
\hline \multicolumn{1}{c}{ Locations } & \# of hives & \# of bees & $\begin{array}{c}\text { Mean \# of alleles per } \\
\text { locus }\end{array}$ & $\begin{array}{c}\text { Mean } \\
\mathrm{H}_{\text {obs }}\end{array}$ & $\begin{array}{c}\text { Mean } \\
\mathrm{H}_{\text {exp }}\end{array}$ \\
\hline 1. Hancayi & 9 & 90 & $1.5 \pm 0.3$ & $0.120 \pm 0.081$ & $0.108 \pm 0.070$ \\
2. Sefar & 3 & 30 & $1.3 \pm 0.2$ & $0.017 \pm 0.011$ & $0.027 \pm 0.018$ \\
3. Zanjan & 12 & 117 & $1.7 \pm 0.3$ & $0.053 \pm 0.037$ & $0.065 \pm 0.046$ \\
4. Gholikandy & 12 & 120 & $1.5 \pm 0.2$ & $0.046 \pm 0.031$ & $0.043 \pm 0.028$ \\
5. Gultepe & 4 & 38 & $1.3 \pm 0.2$ & $0.026 \pm 0.017$ & $0.026 \pm 0.016$ \\
6. Duzteran & 6 & 60 & $1.3 \pm 0.2$ & $0.050 \pm 0.041$ & $0.045 \pm 0.036$ \\
\hline
\end{tabular}

* Corresponding author: kandemir@karaelmas.edu.tr 


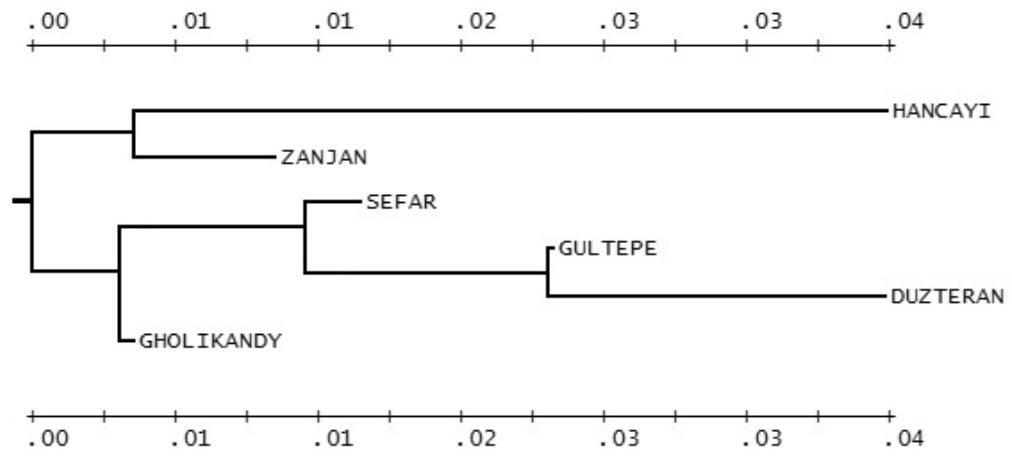

Figure 1. Distance Wagner tree based on Prevosti distance of allozyme data of six honey bee populations in Iran.

Hancayi and Gultepe respectively. Overall mean heterozygosity for all populations was calculated as $0.052 \pm 0.036$. We did not observe any introgression between Iranian and Turkish honey bees. $M d h^{116}$ allele was observed in Eastern locations in Turkey (Kandemir et al., 2000), but this allele was not present in Iran. Similarly there was no variation in Est locus in Eastern Turkey, however, it was variable in one of the populations in Iran. The Pgm locus was highly variable in Turkey, in contrast to being only slightly variable in Iran.

Iranian populations were highly variable at the $M d h$ locus. Allele frequencies in Mdh show a clinal variation in Turkey (Kandemir et al., 2000) and this phenomenon has been known from other regions (Nielson et al., 1994). The frequency of the $M d h^{65}$ allele is high in some European honey bee populations, declining gradually towards the east and finally disappearing in southern Turkey (Kandemir et al., 2000). However, this allele occurred in Iran with high frequency, especially in highland populations. One possible interpretation of this phenomenon is the differential stability of $M d h$ alleles at different environmental temperatures as reported by Cornuet et al. (1995). The highest and the lowest differentiation $\left(\mathrm{F}_{\mathrm{ST}}\right)$ among populations was due to $H k$ and Est enzymes respectively.

Distance Wagner clustering divided honey bee populations into two groups as lowland and highland populations (Fig. 1) except Sefar population. However, the overall results clearly support the existence of two distinct populations as detected by morphometrics (Ruttner et al., 2000). Detailed sampling and additional data from mtDNA RFLP, sequencing and microsatellite analysis together with morphometrics should help to resolve Iranian honey bee population structure.

\section{ACKNOWLEDGMENTS}

We thank Dr. W.S. Sheppard, Dr. M.D. Meixner, Dr. I. Togan and Dr. Z. Kaya for discussions, comments and laboratory support.
Note scientifique sur la variabilité allozymique chez Apis mellifera meda dans les monts de l'Elbourz en Iran.

Eine wissenschaftliche Notiz über die Allozymvariabilität in Apis mellifera meda vom Elburzgebirge im Iran.

\section{REFERENCES}

Cornuet J.M., Oldroyd B.P., Crozier R.H. (1995) Unequal thermostability of allelic forms of malate dehydrogenase in honey bees, J. Apic. Res. 41, 45-47.

Kandemir I., Kence A. (1995) Allozyme variation in a Central Anatolian honey bee (Apis mellifera L.) populations, Apidologie 26, 503-510.

Kandemir I., Kence M., Kence A. (2000) Genetic and morphometric variation in honey bee (Apis mellifera L.) populations of Turkey, Apidologie 31, 343-356.

Nielson M.A., Page R.E. Jr., Crosland M.W.J. (1994) Clinal variation and selection of MDH allozymes in honey bee populations, Experientia 50, 867871.

Ruttner F. (1988) Biogeography and Taxonomy of Honey bees, Springer-Verlag, Berlin.

Ruttner F., Elmi M.P., Fuchs S. (2000) Ecolines in the Near East along $36^{\circ}$ latitude in Apis mellifera $\mathrm{L}$., Apidologie 31, 157-165.

Ruttner F., Pourasghar D., Kauhausen D. (1985) Die Honigbienen des Iran 2 Apis mellifera meda Skor, die Persische Biene, Apidologie 16, 241-264.

Sheppard W.S., Smith D.R. (2000) Identification of African-derived bees in the Americas: A survey of methods, Ann. Entomol. Soc. Am. 93, 159176.

Swofford D.L., Selander R.B. (1981) BIOSYS-1: a fortran program for the comprehensive analysis of electrophoretic data in population genetics and systematics, J. Hered. 72, 281-283. 